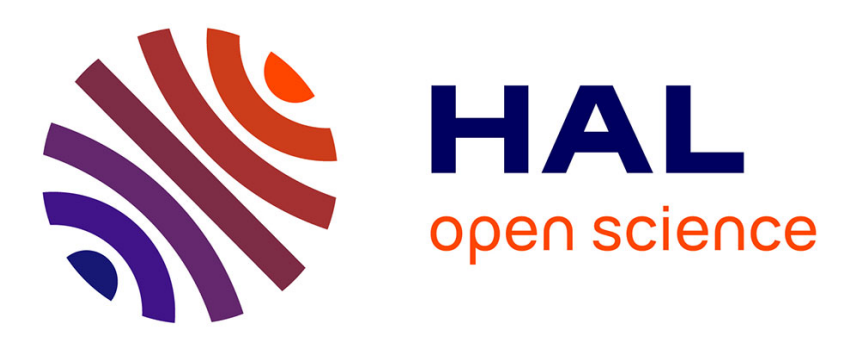

\title{
Variation of thermal plasticity for functional traits between populations of an invasive aquatic plant from two climatic regions
}

Gabrielle Thiébaut, Michèle Tarayre, Olivier Jambon, Nathalie Le Bris, H Colinet, D Renault

\section{To cite this version:}

Gabrielle Thiébaut, Michèle Tarayre, Olivier Jambon, Nathalie Le Bris, H Colinet, et al.. Variation of thermal plasticity for functional traits between populations of an invasive aquatic plant from two climatic regions. Hydrobiologia, 2021, 848 (9), pp.2077-2091. 10.1007/s10750-020-04452-2 . hal02993311

\section{HAL Id: hal-02993311 \\ https://hal.science/hal-02993311}

Submitted on 13 Nov 2020

HAL is a multi-disciplinary open access archive for the deposit and dissemination of scientific research documents, whether they are published or not. The documents may come from teaching and research institutions in France or abroad, or from public or private research centers.
L'archive ouverte pluridisciplinaire HAL, est destinée au dépôt et à la diffusion de documents scientifiques de niveau recherche, publiés ou non, émanant des établissements d'enseignement et de recherche français ou étrangers, des laboratoires publics ou privés. 
1 Variation of thermal plasticity for functional traits between populations of an invasive 2 aquatic plant from two climatic regions

3 Gabrielle Thiébaut $^{1 *}$, Michèle Tarayre ${ }^{1}$, Olivier Jambon ${ }^{1}$, Nathalie Le Bris ${ }^{1}$, Hervé Colinet ${ }^{1}$,

4 David Renault ${ }^{1,2}$

5

6 ' ${ }^{1}$ Univ Rennes, CNRS, ECOBIO [(Ecosystèmes, biodiversité, évolution)] - UMR 6553, F-35000

7 Rennes, France

$8 \quad{ }^{2}$ Institut Universitaire de France, 1 Rue Descartes, 75231 Paris cedex 05, France

9

$10 *$ Corresponding author 
13 Temperature inducible phenotypic plasticity is a major player in plant reponses to climate warming. Functional responses and their role in determining thermal plasticity of plants remain poorly understood. Our objective was to compare trait responses of six populations of Ludwigia peploides resulting from seed from Oceanic climate and from Mediterranean climate after an exposure at three temperatures $\left(16{ }^{\circ} \mathrm{C}, 24{ }^{\circ} \mathrm{C}\right.$, and $\left.30^{\circ} \mathrm{C}\right)$. A comparative analysis showed that at $30^{\circ} \mathrm{C}$ the six populations of $L$. peploides shared different morphological responses, whereas a common pattern of morphological responses were found for the six populations at $16{ }^{\circ} \mathrm{C}$. At $16{ }^{\circ} \mathrm{C}$, the growth was very low suggesting a stress. At $30{ }^{\circ} \mathrm{C}$, the three Mediterranean 21 populations of $L$. peploides accumulated $\approx 7$ fold more total biomass than the populations from 22 Oceanic region. Despite drawing similar response pattern to temperature, the populations 23 showed several different metabolic responses. The thermal plastic responses to the highest temperature differed according to the origin of the populations. The Mediterranean populations of $L$. peploides could be better adapted to rising temperature. These abilities could allow them to take advantage from climate warming if the temperature is not warming up to temperature above a critical threshold.

Keywords : morphological traits, physiological traits, metabolome approach, climate warming, Ludwigia peploides, 


\section{Introduction}

Environmental changes, including climate change, have profound impacts on life history traits of aquatic plant species, in turn affecting population dynamics and community structure in lakes and streams (Meerhof al., 2012; Salinas et al., 2018). In addition to rising temperature, several climatic models predict that the frequency and magnitude of temperature extremes will likely increase in the future (Seneviratne et al., 2012). These worldwide changes in climatic features will modify climate envelopes, increasing the number of suitable habitats and promoting the establishment and spread of invasive species (Bellard et al., 2013; Gillard et al., 2017a). Warming freshwaters have profound effects on aquatic plant species (Madsen \& Brix, 1997; Hussner et al., 2014; Hyldgaard et al., 2014), on the community composition (Netten et al., 2010; 2011) or long term effects within thermal abnormal waters (Hussner, 2014). Consistently, Da Silveira \& Thiébaut (2017) reported the beneficial effects of rising temperature for the relative growth rate of the Canadian pondweed Elodea canadensis Michaux and the Brazilian waterweed Egeria densa Planch. and concluded that warming should further support a shift in the geographical range of E canadensis.

The ever-changing conditions of habitat characteristics of living organisms give a central role to phenotypic plasticity, i.e. the ability of a particular genotype to express a range of phenotypes across different environments (Bradshaw, 1965), which may be adaptive (van Kleunen \& Fischer, 2005; Richards et al., 2006). By allowing real-time changes of the morphology and physiology of the individual, environmental modifications can be tracked in order to maintain the highest possible fitness (Richards et al., 2006; Nicotra et al., 2010). Adaptive plasticity has been reported as one of the key features of invasive populations as compared with natives (Davidson et al., 2011), with invasive macrophytes being able, for instance, to invade climatic niches quite different than those of their area of origin (Gillard et al., 2017a). 
A range of physiological mechanisms such as accumulation of osmolytes or changes in the composition of sugars or on the carbohydrate contents, can filter the effects of thermal fluctuations in ectothermic animals and plant species (Colinet et al., 2015, Sulmon et al., 2015; Koussoroplis et al., 2017), enhancing the level of trait plasticity. In this context, plant functional traits, which connects growth, reproduction and survival to the fitness of the individual (Violle et al., 2007), represent straightforward measures for the evaluation of organism responses to environmental factors, including habitat temperature. For instance, Riis et al. (2012) showed increased Relative Growth Rate values in E. canadensis grown at $25^{\circ} \mathrm{C}$ as compared with their relatives maintained at $20^{\circ} \mathrm{C}$ or $30^{\circ} \mathrm{C}$. This example of $E$. canadensis illustrates, that warming as such will not generally causes faster growth, whereas Li et al. (2017) showed that the total biomass and number of flowers of Myriophullum spicatum (L.) increased with climate warming and heat wave events. Moreover, physiological traits, including metabolic activities, are core mechanisms allowing plants to cope with climate change (Sun et al., 2016). Consistently, the accumulation of osmolytes (i.e. low-molecular weight organic compounds) has been repeatedly demonstrated in plants exposed to challenging temperature conditions (reviewed in Vincente et al., 2016). Osmolytes stabilize proteins to thermal and chemical denaturation. Other examples include the temperature-induced changes in the composition of primary metabolites like sugars (Thouvenot et al., 2015). Notably decreased sugar levels were reported in different plant species in response to increasing temperature (Sun et al., 2016; Gillard et al., 2017b). Sucrose can be quickly mobilised and stored throughout the plant and used for respiratory needs while gross morphological and biochemical changes occur during acclimation (Sun et al., 2016). As a result, examining functional traits of invasive populations provides a useful framework for the assessment of their responses to future climate change. As local conditions are strong drivers of phenotypic plasticity (King et al., 2018), the responses of geographically separated populations collected from contrasted climatic conditions would provide valuable comparisons 
of their potential differences (Sultan \& Spencer, 2002; Drenovsky et al., 2012; Gillard et al., 2020), in turn improving information for making predictions of future geographic expansion. The breadth of the thermal tolerance range of organisms often matches with the climatic conditions of the habitats and regions where it thrives, as described by the climatic variability hypothesis $(\mathrm{CVH})$. Accordingly, a positive relationship between thermal tolerance ranges and latitude has been reported in the worldwide submerged plant Stuckenia pectinata (L.) (Pilon \& Santamaria, 2002). In this species, higher-latitude populations could escape from low temperatures by growing later in the season, or by postponing their reproductive phase. Another example is provided by the comparison of southern and northern European submerged plants which may show a perennial or winter-annual life cycle in the south, while at higher latitudes populations are most frequently summer annuals (Van Wijk, 1988). This illustrates the importance of considering intraspecific variation in plasticity and trait when investigating the effects of climate change on living organisms. This knowledge will refine our understanding of the range of responses exhibited by invasive plants, and improve predictions of their potential proliferation and spread success under climate warming.

Among the most invasive aquatic plants in the world, the creeping water primrose Ludwigia peploides subsp. montevidensis (Spreng.) P.H.Raven causes many significant changes to ecological processes and structures by reducing water flow and by altering hydrological regimes (Dandelot et al., 2005). Dense infestations of emergent macrophytes can dramatically reduce the dissolved oxygen (DO) concentrations in water by reducing water circulation and increasing biological oxygen demand from high biomass production and subsequent in situ decomposition of organic matter. L. peploides was introduced from the South America to Montpellier in France in the 1830s, likely as a result of ornamental plantings (Dandelot et al., 2005). It has since become a widespread aquatic invasive plant in the south of France and along the Atlantic coast. In the northwestern part of France, L. peploides started to 
106 colonize the Loire River watershed by the end of the 1970s, and has spread rapidly among

107 several water bodies (Ruaux et al., 2009). Nowadays, L. peploides has a wide distribution in 108 Europe (EPPO, 2011; Thouvenot et al., 2013). Recent modeling efforts using CLIMEX (EPPO 109 2011) and species distribution models (Gillard et al., 2017a) predict that Ludwigia spp. has the 110 potential to spread invasively into higher latitudes in Europe. At the European level, the water 111 primrose belongs to the first European Union list of 37 invasive species adopted by the 112 European Commission in July 2016. The plant demonstrates a high degree of phenotypic 113 plasticity, which allows it to adapt to a broad range of growing conditions and water regimes

114 (Ruaux et al., 2009; Billet al., 2018). It is mainly aquatic, but is also able to colonise terrestrial 115 habitats such as riverbanks and wet meadows (Thouvenot et al., 2013). Under controlled 116 conditions, Yen \& Myerscough (1989) noted the absence of L. peploides when the temperature 117 of the water remains below $20^{\circ} \mathrm{C}$, and when present, cooler temperatures can highly delay the 118 development of water primroses (Thouvenot et al., 2013). Ludwigia peploides has weak growth 119 at atmospheric temperatures of $10{ }^{\circ} \mathrm{C}$ and very high growth at $40{ }^{\circ} \mathrm{C}$, but without flower 120 production (Yen \& Myerscough, 1989).

121 In the present study, we aimed at comparing the effects of warming temperature on the 122 morphological and physiological traits of the invasive water primrose L. peploides collected 123 from two French different geographic regions. Three independent populations were sampled 124 respectively from Mediterranean and from Oceanic regions in France, and subsequently 125 cultured under controlled conditions. To explore whether trait values varied among these 126 populations when exposed at three different temperatures, and if the source regions were 127 predictors of these differences, we measured morphological (main shoot length, number of 128 lateral branches and leaves, relative growth rate, above and below ground biomass, total 129 biomass) and physiological (flavonols, anthocyanins, chlorophyll, and nitrogen balance 130 indexes), in addition to obtaining metabolic phenotypes of the plants (GC-MS metabolomics). 
131 We hypothesized that 1) individuals of L. peploides would exhibit variation in plant trait values

132 when grown at increasing temperatures; 2) Mediterranean populations would perform better 133 than those from Oceanic climate at high temperatures.

\section{Materials and methods}

For the purpose of this work, we selected six populations of L. peploides from two source regions (three populations of northwestern France and three populations of southeastern France) differing in their climatic variables. For each sampled population, mature capsules were collected in October 2017 from individuals separated by at least $10 \mathrm{~m}$ in order to increase the likelihood of subsequently working with distinct individuals.

One set of three distinct populations was sampled from southeastern France (hereafter referred to as Mediterranean France): the sampling habitats are located in the Köppen climate zone Csa, corresponding to a hot-summer Mediterranean climate and a dry summer season. In this region, the three populations were collected from (i) a small drained pond with emergent wetland plants (Marais de Coute, MACO), (ii) Canal des Capettes (CCAP), a tributary artificial channel of Petit Rhône River, and (iii) in a marshland (population CAM) (Table 1).

A second set of three populations was collected from three sites in northwestern France 148 (hereafter referred to as Oceanic France) which is characterized by a temperate Oceanic climate

149 having a warm summer season, but no dry season; these sampling sites are categorized as Cfb 150 according to the Köppen climate classification (Belda et al., 2014).. These three populations of 151 L. peploides were sampled from (i) oxbows of the Loire River at Ile Joli Coeur (LRJC), (ii) at 152 Port de Vallières (LRPV), and (iii) in a marshland (population BRB) (Table 1). After collection, capsules were dried out at ambient temperature before being stored at $4^{\circ} \mathrm{C}$ in the dark until being cultured. In March 2018, twenty capsules of each population were soaked in tap water at $4{ }^{\circ} \mathrm{C}$ for a week, and then dissected to extract seeds. For each population, 
200 seeds (10 seeds from each of the 20 capsules) were placed in a climatic chamber cycling

157 from $19^{\circ} \mathrm{C}$ to $24^{\circ} \mathrm{C}$ (night / day) with a $14 \mathrm{~h}$ day/10 h night photoperiod to produce seedlings

158 for the subsequent setting of the experiment. Seedling emergence and seedling growth were

159 monitored over a period of 42 days. In early April 2018, the length of the primary stem of the

160 largest seedlings was monitored every other day, and all seedlings were grown until there were

161 a minimum of 35 individuals having primary stem lengths of at least $4 \mathrm{~cm}$ in each population.

162 In mid-April, a stratified random selection of the plant based on primary stem length was done,

163 allowing to sample 24 individuals from each population for the measurements of morphological

164 and physiological traits, and nine individuals from each population for the metabolomic 165 approach.

\section{Description of the thermal treatments}

The seedlings were transplanted individually into $200 \mathrm{cL}$ pots $(\mathrm{L} \times \mathrm{W} \times \mathrm{H} ; 5 \mathrm{~cm} \mathrm{x} 5 \mathrm{~cm}$ x $7 \mathrm{~cm})$ filled with a $1: 1(\mathrm{v} / \mathrm{v})$ mixture of fine sand and potting soil. Initial nitrogen $(\mathrm{N})$, phosphorus $(\mathrm{P})$ and potassium $(\mathrm{K})$ primary macronutrient concentrations were at NPK 14-1018 percentages by soil mass. Plants were then placed for a period of four weeks into three growing chambers differing by their diurnal temperature regimes: for each population, one plant group $\left(\mathrm{N}=8\right.$ replicates) was maintained at $16 / 11{ }^{\circ} \mathrm{C}$ (day/night, $14 / 10 \mathrm{~h}$ ) (mean annual temperature of Oceanic region), a second plant group at $24 / 19{ }^{\circ} \mathrm{C}$ (mean annual temperature of Mediterranean region) (day/night, $14 / 10 \mathrm{~h}$ ), and a third group at $30 / 25^{\circ} \mathrm{C}$ (Climate warming, worse scenario) (day/night, 14/10 h). The climate warming temperature has been chosen 176 according to the worst ICPP climatic scenario (RCP 8.5). For the daylight period (14h), a 177 photosynthetic photon flux density of $350 \mu \mathrm{mol} \mathrm{m} \mathrm{m}^{2} \mathrm{~s}^{-}{ }^{1}$ was used for all experimental conditions. Relative humidity was set to $60 \%$. The three different temperature regimes will have strongly different vapour pressure deficits (VPD), and higher VPD might result in acclimations to reduce the water loss (physiologically by e.g. increased stomatal resistance), which will affect 
181 growth and biomass related traits as well as biochemical characteristics. The water level was

182 adjusted manually during the growth period.

\section{Measurement of physiological traits during the thermal treatment}

We used a functional trait approach to monitor the physiological responses of individual L. peploides plants of the six populations during the four-week exposure at one of the three temperature regimes. Four physiological traits were simultaneously monitored in vivo using a non-destructive measurement device called the Dualex Scientific ${ }^{+\mathrm{TM}}$ sensor. This hand-held leaf-clip sensor (Cerovic et al., 2012; Burling et al., 2013) allows obtaining indicator values of the amounts of flavonols (Flav), anthocyanins (Anth.) and chlorophyll (Chl.) in the leaves. The $\mathrm{Chl}$ index related to the chlorophyll content (between 0 and 150) is a proxy to the Photosynthetic yield. The Flav. index related to the flavonol content or to phenolics accumulation is an indicator to the defense mechanisms against pathogens and herbivores. The Anth. index related to anthocyanin is an indicator of an exposure to stress (shading conditions, nutrient deficiencies, temperature stress etc.). The sensor also calculates the nitrogen balance index (NBI), which represents an indicator of changes in $\mathrm{C} / \mathrm{N}$ allocation as a result of $\mathrm{N}$-deficiency (from 0 to 100 ) rather than a measure of leaf nitrogen content per se. The measurements of physiological traits were all taken from one apical leaf of one individual per population of $L$. peploides and per thermal regime every 4-5 days over the four-week period, thus ending up with six different temporal measures repeated on the same individuals.

\section{Measurement of morphological traits at the end of the thermal treatment}

At the end of the four-week exposure, for each experimental condition and for each population, the main shoot length was measured and the lateral branches and the number of leaves were counted. The roots and shoots were harvested separately, placed into paper bags, dried out at $65{ }^{\circ} \mathrm{C}$ for $72 \mathrm{~h}$, and weighed (dry mass). The Relative Growth Rate (RGR; $\mathrm{d}^{-1}$ ) was calculated, as proposed by Hunt (1990): 

and at the end of the experiment (T2), respectively.

At the end of the thermal treatment, the leaves of each plant were collected, resulting in the constitution of 3 to 5 replicates per population and per temperature regime. After collection, leaves were snap-frozen into liquid nitrogen and stored at $-80^{\circ} \mathrm{C}$. Before the analyses, leaves were lyophilized, and reduced into powder. For each replicate, 5 to $10 \mathrm{mg}$ of plant material were weighed. We used the extraction procedure described by Serra et al. (2013). Briefly, each replicate was homogenized in $1125 \mu \mathrm{L}$ of a solution of ice-cold methanol/chloroform $(2: 1, \mathrm{v} / \mathrm{v})$.

216 Then, a volume of $750 \mu \mathrm{l}$ of ultra-pure water was added. Samples were homogenized and 217 centrifuged for $10 \mathrm{~min}$ at $4,000 \mathrm{~g}\left(4^{\circ} \mathrm{C}\right)$. Twenty $\mu \mathrm{L}$ of the upper phase containing metabolites 218 was transferred to new glass vials. Samples were vacuum dried (Speed Vac Concentrator, 219 MiVac, Genevac Ltd., Ipswich, England). The derivatization of the samples was conducted 220 with a CTC CombiPAL autosampler (CTC Analytics AG, Zwingen, Switzerland), as described 221 in Khodayari et al. (2013). The GC-MS platform consisted of an Agilent $7890 \mathrm{~B}$ gas 222 chromatograph coupled to a 5977B mass spectrometer. The injector was held at $250{ }^{\circ} \mathrm{C}$, and 223 the temperature of the oven ranged from 70 to $170{ }^{\circ} \mathrm{C}$ at $5^{\circ} \mathrm{C}$ per min, from 170 to $280{ }^{\circ} \mathrm{C}$ at 7 $224{ }^{\circ} \mathrm{C}$ per min, and from 280 to $320^{\circ} \mathrm{C}$ at $15{ }^{\circ} \mathrm{C}$ per min; at the end of the temperature ramps, the 225 oven remained at $320^{\circ} \mathrm{C}$ for $4 \mathrm{~min}$. A $30 \mathrm{~m}$ fused silica column (HP5 MS $30 \mathrm{~m}$, I.D. $0.25 \mathrm{~mm}$, 226 thickness $0.25 \mu \mathrm{m}, 5 \%$ Diphenyl / 95\% Dimethylpolysiloxan, Agilent Technologies) was used, 227 with helium as the gas carrier at $1 \mathrm{~mL}$ per min. For the transfer line and ion source, temperatures were 280 and $230^{\circ} \mathrm{C}$, respectively. The split mode (split ratio: $2: 1$ ) was used for the injection 229 of $1 \mu \mathrm{L}$ of each sample, and detection was realized by electronic impact (electron energy: 70 
$\mathrm{eV}$ ), in full scan mode. The detected peaks were annotated with MassHunter. Concentration of

231 each metabolite was calculated using individual quadratic calibration curves.

\section{Statistical analysis}

All analyses were performed with R (R Core Team, 2016). Morphological traits were analysed using generalized linear models (GLMs) with «population» (6 levels) and « temperature » (3 levels) as fixed and crossed variables. The effects of each variable and the interaction were analysed via the analysis of deviance (ANOVA function in "car" package; Fox, 2003). Post-hoc comparisons were based on least-squares means using the "lsmeans" package (Russell, 2016). For physiological traits, data from the three individuals (and populations) originating from Oceanic region (i.e. BRB, LRJC, LRPV; Table 1) or from Mediterranean region (i.e. CAM, MACO, CCAP; Table 1) were grouped to assess the "Region" effect. As physiological traits were repeatedly measured on the same individuals during growing period, the identity of each plant was included in a generalized linear mixed-effects model as a random effect to account for repeated measures, using lmer function in the "Ime4" package for R (Bates et al., 2015). The model tested the effects of time (6 time points), region (OFR vs. MFR) and growing temperature regime $\left(16,24,30^{\circ} \mathrm{C}\right)$, as well as all interactions. The effects of variables were assessed with ANOVA function using the "car" package and posthoc comparisons were done using the "Ismeans" package. Metabolic compositions of the plants were compared using between-class PCA in the "ade4" package in R (Dray \& Dufour, 2007). Monte Carlo tests were performed to examine the significance of the difference among the classes (based on 1,000 simulations). To identify the variables (i.e., metabolites) contributing the most to the PCA structure separation, the correlations to the principal components (PCs) were extracted and integrated into correlation circles; correlations values of each compound to PC1 and PC2 are shown in Table S1. 


\section{Results}

\section{Changes in plant morphological traits}

The population, temperature, and the interaction of these terms, significantly affected all of the measured morphological traits related to growth, biomass, leaf and shoot production (Table 2). At $16^{\circ} \mathrm{C}$, the below and above ground biomasses were very low in individuals of $L$. peploides (Fig. 1). No lateral shoots were produced, there was low production of new leaves, all of these measurements ending up in a very small RGR value for all populations. While no striking difference was observed for the production of new leaves among the six populations exposed at $24^{\circ} \mathrm{C}$, the production of lateral shoots, below and above ground biomasses, and total biomass tended to be significantly higher in the three Mediterranean populations as compared with their three Oceanic relatives. A similar pattern was reported from the plants exposed at 30 ${ }^{\circ} \mathrm{C}$ (Fig. 2). At this temperature, the production of lateral shoots, above ground biomass and total biomass were higher than those measured at $24{ }^{\circ} \mathrm{C}$ for the plants from the Mediterranean region. Overall, a higher number of new leaves produced in plants from both geographic regions exposed at $30{ }^{\circ} \mathrm{C}$ as compared with those that were exposed at $24^{\circ} \mathrm{C}$, RGR was highly significantly increased from $16^{\circ} \mathrm{C}$ to $24^{\circ} \mathrm{C}$, but then remained more or less similar when temperature was further increased.

\section{Changes in plant physiological traits}

The effects of geographic origin of the plants (Mediterranean versus Oceanic), temperature, and the interaction of these terms, on the physiological traits of the plants are presented in Table 3. All physiological traits were significantly affected by the temperature of the experiment, the geographic origin of the plants, the timing of the measurement, and the interaction temperature : timing of the measure. A similar changing pattern was observed for the six populations of L. peploides, with Nitrogen balance and chlorophyll indexes being increased from 16 to $30^{\circ} \mathrm{C}$, while flavonol and anthocyanin indexes were decreased over this 
thermal range (Fig. 2). Conversely, the indices depicting Nitrogen balance index, chlorophyll 280 and anthocyanin amounts were higher in Mediterranean plants at $16^{\circ} \mathrm{C}$, and the difference with 281 Oceanic plants disappeared when temperature was increased, except for chlorophyll.

\section{Metabolic phenotypes of the six populations of L. peploides}

The PCA showed that $86 \%$ of the changes in metabolite amounts were explained by the two first axes (Fig. 3). The first axis of the PCA accounted for $68 \%$ of the total inertia, and was mainly constructed by the higher amounts of galactose, glucose $6 \mathrm{P}$, inositol, malate acid, ornithine, succinic acid and quinic acid, which were measured in higher amounts in individuals

of L. peploides exposed at $16{ }^{\circ} \mathrm{C}$. The second axis of the PCA, accounted for $18 \%$ of the total inertia, was mainly defined by the higher amounts of aspartic acid, fumaric acid, and glycine which tended towards higher concentrations at $30{ }^{\circ} \mathrm{C}$ (Fig. 3). In addition to the similar temperature-driven metabolic pattern reported from the six $L$. peploides populations, in-depth analysis of the measured amounts of the different metabolites revealed several differences (Fig. 4). Specifically, seedlings from the LRPV population were characterized by their high levels of galactose, glucose 6P, inositol, malic acid, mannose, ornithine, saccharose, and xylose (Fig. 4). A clear cut separation appeared between MACO population at $30{ }^{\circ} \mathrm{C}$ and the others populations both at $24{ }^{\circ} \mathrm{C}$ and $30{ }^{\circ} \mathrm{C}$ in the second axis. At $30{ }^{\circ} \mathrm{C}$, seedlings from the MACO population were characterized by their high levels of ethanolamine, glycine and fumaric acid (Fig. 4). of L. peploides from distinct climatic conditions would be characterized by different abilities 
traits were found, thus confirming the local adaption of the sampled populations, in line with

305 the climate variability hypothesis. At the lowest temperature we tested $\left(16^{\circ} \mathrm{C}\right)$, most of the traits (biomass accumulation, Relative Growth Rate, production of new leaves, nitrogen uptake,

307 photosynthetic activity) remained at very low levels in seedlings from all populations. The quasi 308 absence of plant growth is consistent with a former study conducted in Ludwigia grandiflora 309 (Michx.) Greuter \& Burdet, and reporting a weak growth at $10{ }^{\circ} \mathrm{C}$ (Yen \& Myerscough, 1989).

310 Our results suggest that $16{ }^{\circ} \mathrm{C}$ may be largely suboptimal for the plants, as supported by the 311 increased values of the anthocyanin index. These water soluble pigments enhance cold 312 tolerance when accumulated in plant tissues, as earlier reported in a range of plant taxa 313 (reviewed in Chalker-Scott 1999). Moreover, the inhibition of stem length and lateral shoot 314 production are also well-characterized responses of plants exposed at low temperatures (Da 315 Silveira \& Thiébaut, 2017, Riis et al., 2012). Conversely, the growth and development of the 316 individuals from the six tested populations exposed at $24{ }^{\circ} \mathrm{C}$ continued, with significant energy 317 allocation to growth and nitrogen uptake, as revealed by the NBI index. Previous study showed 318 that L. peploides was characterized by a rapid growth and allocation of most biomass and 319 nitrogen into above ground plant parts when developing under Mediterranean climates 320 (Rejmánková, 1992). The optimum development of emerged leaved plants such as Ludwigia occurs between $25{ }^{\circ} \mathrm{C}$ and $35^{\circ} \mathrm{C}$ and these air temperatures will likely occur along the Mediterranean coast during summer. The Oceanic region actual air temperatures are frequently lower than the above suggested thermal optima, optimal photosynthetic activities may be currently limited to short 325 climatic windows in summer periods. Thus, the current temperature characteristics of Oceanic regions should highly restrict the development of this plant species, also because other abiotic 327 factors (e.g. irradiance and $\mathrm{CO}_{2}$ availabilities) that can also constrain the performance of photosynthetic reactions may be characterized by different variation patterns than those of 
temperature. Rising air temperature increases saturated water vapor pressure. An increase in air

330 vapor pressure deficit (VPD), affects plant physiology independently of other drivers associated

331 with climate change, for example elevated carbon dioxide concentrations $\left(\left[\mathrm{CO}_{2}\right]\right)$. Stomatal

332 conductance declines under high VPD and transpiration increases in most species up until a 333 given VPD threshold, leading to a reduction of photosynthesis and growth, and higher risks of 334 carbon starvation (Day, 2013).

The chlorophyll index was almost doubled in Oceanic L. peploides plants exposed at 30

${ }^{\circ} \mathrm{C}$ relative to those exposed at $16{ }^{\circ} \mathrm{C}$. Yet, the lower values of chlorophyll for these populations are intriguing, and this typical response of cold-stressed plants, and symptomatic of oxidative stress, has not been observed in plants from the Mediterranean region. The Mediterranean populations perform better than the Oceanic populations with regard to chlorophyll, at all 340 temperatures. Our second hypothesis was validated. More interesting, the Mediterranean populations produced more chlorophyll at $16{ }^{\circ} \mathrm{C}$ than the Oceanic populations, even though

342 they are adapted to higher temperatures. The apparent higher sensitivity of chlorophyll 343 production, and thus photosynthetic activities of these individuals suggests that populations 344 from this region should highly benefit from future warming. Interestingly, most of the differences observed for trait responses among the six plant 346 populations were largely determined by the climate regions where seeds were collected. At 30

$347{ }^{\circ} \mathrm{C}$, the three populations originating from the Mediterranean region allocated more energy to 348 biomass in general, and to the production of lateral shoots rather than to apical growth. These 349 results are congruent with available literature (Rejmankova, 1992), and with a mesocosm 350 experiment conducted in California (Gillard et al., 2020). Indeed, Gillard et al. (2020) 351 established that a higher climatic similarity in the source and invaded regions greatly assists the 352 establishment and performance of L. peploides. Overall, we found that Mediterranean populations of $L$. peploides performed significantly better at $30{ }^{\circ} \mathrm{C}$ than those from Oceanic 
populations. This finding, in accordance with the climatic variability hypothesis, suggests that

355 the populations have adapted locally to their environmental conditions. As a result, the larger dissimilarity between the temperature characteristics of their original habitat and the thermal regimes may contribute to explaining the highly reduced performance of these populations at 358 high temperature.

\section{Different metabolic responses to temperature}

Several studies have employed metabolic profiling to describe changing physiological dynamics in plants exposed to different temperature regimes, in addition to evidencing the set of metabolites characterizing acclimation to cold or heat temperatures (reviewed in Shulaev et al., 2008). Variations in metabolite contents is essential for maintaining optimal metabolic phenotype and overall, trait-environment matching; during changes of temperature conditions, amino acid, sugar, and Krebs cycle intermediate metabolites acting as osmolytes, antioxidants, byproducts of stress exposure, and signal transduction are expected to vary (Xu et al., 2020). In our study, higher levels of galactose, glucose $6 \mathrm{P}$, and succinic acid were measured from the leaves of L. peploides after they were exposed at low temperature for 4 weeks. The accumulation of soluble sugars is common in plant leaves whose growth is limited by low temperatures, as for instance found in young tomato plants (Klopotek \& Klaring, 2014). Variations of the amounts of soluble sugars and of some Krebs cycle intermediates, e.g. the accumulated galactose, glucose 6P, malic and succinic acids, parallel the reduced growth rates of L. peploides exposed at $16{ }^{\circ} \mathrm{C}$. Reductions in carbohydrate concentrations in macrophytes

374 typically occur when plants are relying on stored energy to initiate growth of plant tissues until 375 photosynthesis can begin (Wersal et al, 2011). Indeed, Wersal et al., (2011) showed that stolons were the primary storage location of starch in Myriophyllum aquaticum (Vell.) Verdc.. Earlier 377 study also showed that the transfer of Arabidopsis thaliana (L.) Heynh. (Brassicacea) to cold temperature, followed by their return at optimal temperature, increased the need for carbon 
source when growth was resumed, as revealed by lowing amount of sugars and TCA

380 intermediates (Pagter et al. 2017). It has also been suggested that fumaric acid can be highly 381 accumulated in the leaves of Arabidopsis thaliana (Chia et al., 2000), acting as a carbon reservoir for sustaining development and growth of the plant. In this study, the metabolite concentrations of the six L. peploides populations exposed at $16{ }^{\circ} \mathrm{C}$ can be likely considered as a reliable metabolic signature of depressed growth and development of the plants. Oxygen deficiency in plant tissues often correlates with an elevation of the amounts of alanine and, but to a lesser extent, of succinic acid (Billet et al., 2018). In L. peploides exposed at $16{ }^{\circ} \mathrm{C}$, the higher concentrations of lactic acid, an end-product of anaerobic respiration, suggest that both populations may have activated fermentation (Sun et al., 2016). We suggest that low temperature-induced fermentation may serve as an additional way of energy 390 production, in order to meet the demands of plant tissues that could not be fulfilled by respiratory pathways alone.

Amino acids serve as precursors for a large array of metabolites having multiple 393 functions in plant growth and response to various stresses (Sun et al., 2016). These compounds 394 are osmolytes that can accumulate in stressed plants (Shulaev et al., 2008). Yet, we did not find 395 clear signs of amino acid accumulation in any of the six populations exposed at $16{ }^{\circ} \mathrm{C}$. As 396 mentioned earlier, temperatures below $20{ }^{\circ} \mathrm{C}$ progressively reduce the development of $L$. 397 peploides, which is halted around $10^{\circ} \mathrm{C}$. Our metabolic profiles are highly consistent with this 398 earlier suggestion, by showing that the $16{ }^{\circ} \mathrm{C}$ temperature is restricting for the six populations, 399 but not stressful. This idea is also congruent with field observations, as the spread of $L$. 400 peploides in the Oceanic region was particularly evident when summer temperatures reach 24 $401{ }^{\circ} \mathrm{C}$, a finding that may also apply for Ludwigia grandiflora (Gillard et al., 2017b). In the present study, the effect of temperature on the physiological responses of $L$. 403 peploides was also compared for both regions. Higher levels of fumaric and malic acids were 
measured at $30{ }^{\circ} \mathrm{C}$ than at $24{ }^{\circ} \mathrm{C}$. These changes may indicate a stimulation of the photosynthetic activity in this $\mathrm{C} 4$ species, in turn contributing to the higher biomass accumulation we measured. Photoassimilates may be used for lateral growth, which would be consistent with the observed significant increase of this morphological trait at $30^{\circ} \mathrm{C}$ for Mediterranean populations. A similar malic acid accumulation has been shown in other C4 macrophytes (Beer \& Wetzel, 1982; Bowes et al., 2002), including in Ludwigia hexapetala (Gillard et al.,2017b). At $30^{\circ} \mathrm{C}$, a strong decrease in Glucose 6P and in saccharose contents in Oceanic populations of L. peploides was measured, whereas this change was less evident in Mediterranean populations. This high temperature may have stimulated the photosynthesis of the Oceanic populations of L. peploides, which would have resulted in enhanced carbohydrate production, in fine contributing to the

414 greater apical growth of Oceanic populations at $30^{\circ} \mathrm{C}$. Importantly, the allocation of energy to apical growth and not to the lateral growth is usually considered as an escape strategy (Puijalon et al., 2008) to avoid stress due to the high temperature homeostasis within the organisms through acclimation responses. Physiological responses include the accumulation of compatible solutes in the form of polyols, sugars or amino acids, meaning that metabolic processes should be highly solicited during thermal stress.

\section{Conclusion}

In this study we showed that at $30{ }^{\circ} \mathrm{C}$ the six populations of L. peploides shared different

morphological and physiological responses, whereas at $16{ }^{\circ} \mathrm{C}$ the growth for the six populations

424 was very low suggesting a stress. At $30^{\circ} \mathrm{C}$, the Mediterranean populations of L. peploides 425 perform better than the Oceanic populations. The Mediterranean populations of L. peloides can 426 cope well with high temperatures. Although they did not produced higher biomass than the 427 oceanic populations at low temperature, they were able to induce a higher photosynthetic 428 activity and nutrient uptake than the oceanic populations. The Mediterranean populations of $L$. 
peloides are characterized by a higher plasticity than the oceanic ones. Indeed, our results

430 suggest that the populations growing in the oceanic region somehow lost some of their

431 plasticity. The present results lead to the conclusion that those exotic species whose native

432 habitats are warmer than their introduced ranges would have an advantage in an increasingly

433 heat climate. Research on the response of this species to increasing temperatures in parallel to

434 other environmental factors such as increasing $\mathrm{CO}_{2}$ is required to improve our understanding 435 of the impact of global warming on the invasiveness of aquatic plants. For instance Riis et al. 436 (2012) showed that rate of branching degree for three invasive aquatic plants (Egeria densa,

437 Elodea canadensis and Lagarosiphon major (Ridl.) Moss) suggests that temperature did not 438 influence the general developmental pattern of these plants and light and temperature effects 439 on stem length can counteract each other.

\section{$440 \quad$ Acknowledgments:}

We are grateful to Maxime Planes for their great help with the experiment set up,

442 monitoring and harvest. We would like to thank practioners in South France who provided 443 capsules and access to the sites.

\section{References}

445 1. Bates, D., M. Mächler, B. Bolker \& S. Walker, 2015. Fitting Linear Mixed-Effects 446 Models Using lme4. Journal of Statistical Software 67: 1-51.

447 2. Beer, S. \& R.G. Wetzel, 1982. Photosynthesis in submersed macrophytes of a temperate 448 lake. Plant Physiology 70: 488-492.

449 3. Belda, M., E. Holtanová, T. Halenka \& J. Kalvová, 2014. Climate classification 450 revisited: From Köppen to Trewartha. Climate Research 59: 1-13.

451 4. Bellard, C., W. Thuiller, B. Leroy, P. Genovesi, M. Bakkenes \& F. Courchamp, 2013. 452 Will climate change promote future invasions? Global Change Biology 19: 3740-3748. 
454 morphotypes of the aquatic invasive plant, Ludwigia grandiflora, show distinct morphological 455 and metabolomic responses. Ecology and Evolution 8(5): 2568-2579.

456 6. Bowes, G., S. K. Rao, G. M. Estavillo \& J. B. Reiskind, 2002. C4 mechanisms in aquatic 457 angiosperms: comparisons with terrestrial C4 systems. Functional Plant Biology 29: 379-392. 458 7. Bradshaw, A. D., 1965. Evolutionary significance of phenotypic plasticity in plants. 459 Advances in Genetics 13: 115-155.

460 8. Bürling, K., Z. G. Cerovic, G. Cornic, J-M. Ducruet, G. Noga \& M. Hunsche, 2013. 461 Fluorescence-based sensing of drought-induced stress in the vegetative phase of four 462 contrasting wheat genotypes. Environmental and Experimental Botany 89: 51-59.

463 9. Cerovic, Z.G., G. Masdoumier, N. B. Ghozlen \& G. Latouche, 2012. A new optical leaf464 clip meter for simultaneous non-destructive assessment of leaf chlorophyll and epidermal 465 flavonoids. Physiologia Plantarum 146(3): 251-260.

466 10. Chalker-Scott L., 1999. Environmental Significance of Anthocyanins in Plant Stress 467 Responses. Photochemistry and Photobiology 70(1): 1-9.

468 11. Chia, D., T. Yoder, W. D. Reiter \& S. I. Gibson 2000. Fumaric acid: an overlooked form 469 of fixed carbon in Arabidopsis and other plant species. Planta 211: 743-751.

470 12. Colinet, H., B. J. Sinclair, P. Vernon \& D. Renault, 2015. Insects in fluctuating thermal 471 environments. Annual Review of Entomology 60: 123-140.

472 13. Da Silveira, M. \& G. Thiébaut, 2017. Impact of climate warming on plant growth varied 473 according to the season. Limnologica 65: 4-9.

474 14. Dai, AG. 2013. Increasing drought under global warming in observations and models. $475 \quad$ Nature Climate Change 3: 52- 58.

476 15. Dandelot, S., R. Verlaque, A. Dutartre \& A. Cazaubon. 2005. Ecological, dynamic and 477 taxonomic problems due to Ludwigia (Onagraceae) in France. Hydrobiologia 551: 131-136. 
16. Davidson, A. M., M. Jennions \& A. B. Nicotra, 2011. Do invasive species show higher

479 phenotypic plasticity than native species and, if so, is it adaptive? A meta-analysis. Ecology

480 Letters 14: 419-431.

481 17. Dray, S. \& A. B. Dufour, 2007. The ade4 package: implementing the duality diagram 482 for ecologists. Journal of Statistical Software 22: 1-20.

483 18. Drenovsky, R. E., B. J. Grewell, C. M. Dantonio, J. L. Funk, J. J. James, N. Molinari, I.

484 M. Parker \& C. L. Richards, 2012. A functional trait perspective on plant invasion. Annals of 485 Botany 110: 141-153.

486 19. EPPO, 2011. Pest risk analysis for Ludwigia peploides. Report no. 11-16828. Retrieved 487 from https://gd.eppo.int/downl oad/doc/367_pra_full_LUDPE.pdf

488 20. Fox, J., 2003. Effect displays in R for generalized linear models. Journal of Statistical 489 Software 8: 1-27.

490 21. Gillard, M., G. Thiébaut, C. Deleu \& B. Leroy, 2017a. Present and future distribution 491 of three aquatic plants taxa across the world: decrease in native and increase in invasive ranges. 492 Biological Invasions 19: 2159-2170.

493 22. Gillard, M., B. J. Grewell, C. Deleu \& G. Thiébaut, 2017b. Climate warming and water 494 primroses: Germination responses of populations from two invaded ranges. Aquatic Botany 495 136: 155-163.

496 23. Gillard, M. B., R. E. Drenovsky, G. Thiebaut, M. Tarayre, C. J. Futrell \& B. J. Grewell, 497 2020. Seed source regions drive fitness differences in invasive macrophytes. American Journal 498 of Botany 107(5): 1-12.

499 24. Hunt, R., 1990. Basic Growth Analysis: Plant Growth Analysis for Beginners. 500 Publisher, Springer, Dordrecht.

$50125 . \quad$ Hussner, A., 2014. Long-term macrophyte mapping documents a continuously shift 502 from native to non-native aquatic plant dominance in the thermally abnormal River Erft (North 
Rhine-Westphalia, Germany), Limologica 48: 39-45.

504 26. Hussner, A., X . van Dam, J. E. Vermaat \& S. Hilt, 2014. Comparison of native and 505 neophytic aquatic macrophyte developments in a geothermally warmed river and thermally 506 normal channels. Fundamental and Applied Limnology / Arch für Hydrobiologie 185: 155507166.

508 27. Hyldgaard, B., B. Sorrell \& H. Brix, 2014. Closely related freshwater macrophyte 509 species, Ceratophyllum demersum and C. submersum, differ in temperature response. $510 \quad$ Freshwater Biology 59: 777-788.

511 28. Khodayari, S., S. Moharramipour, V . Larvor, K. Hidalgo \& D. Renault, 2013.

512 Deciphering the Metabolic Changes Associated with Diapause Syndrome and Cold 513 Acclimation in the Two-Spotted Spider Mite Tetranychus urticae. PLoS ONE 8(1): e54025.

514 29. King, N. G., N. J. McKeown, D. A. Smale \& P. J. Moore, 2018. The importance of 515 phenotypic plasticity and local adaptation in driving intraspecific variability in thermal niches 516 of marine macrophytes. Ecography, 41: 1469-1484.

517 30. van Kleunen, M. \& M. Fisher, 2005. Constraints on the evolution of adaptive phenotypic 518 plasticity in plants. New Phytololgist 166: 49-60.

519 31. Klopotek, Y. \& H-P. Kläring, 2014. Accumulation and remobilisation of sugar and 520 starch in the leaves of young tomato plants in response to temperature, Scientia Horticulturae $521 \quad 180: 262-267$.

522 32. Koussoroplis, A. M., S. Pincebourde and A. Wacker, 2017. Understanding and 523 predicting physiological performance of organisms in fluctuating and multifactorial 524 environments. Ecological Monographs 87: 178-197.

525 33. Li, Z. L. He, H. Zhang, P. Urrutia-Cordero, M.K. Ekvall, J. Hollander \& L.-A. Hansson, 526 2017. Climate warming and heat waves affect reproductive strategies and interactions between 527 submerged macrophytes. Global Change Biology 23: 108-116. 
528 34. Madsen, T. V. \& H. Brix, 1997. Growth, photosynthesis and acclimation by two 529 submerged macrophytes in relation to temperature. Oecologia 110:320-327.

$530 \quad 35 . \quad$ Meerhoff, M., F. Teixeira-de Mello, C. Kruk, C. Alonso, I. Gonzalez Bergonzoni, J. P.

531 Pacheco, G. Lacerot, M. Arim, M. Beklioglu, S. B. Balmana, G. Goyenola, C. Iglesias, N.

532 Mazzeo, S. Kosten \& E. Jeppesen 2012. Environmental warming in shallow lakes: A review of 533 potential Changes in community Structure as evidenced from space-for-time substitution 534 approaches. Advances in Ecological Research 46: 259-349.

535 36. Netten, J.J.C., G.H.P. Arts, R. Gylstra, E.H. Van Nes, M. Scheffer \& R.M.M. 536 Roijackers, 2010. Effect of temperature and nutrients on the competition between free-floating 537 Salvinia natans and submerged Elodea nuttallii in mesocosms. Fundamental and Applied 538 Limnology 177: 125-132.

539 37. Netten, J.J.C., J.Van Zuidam,, S. Kosten \& E.T.H.M. Peeters, 2011. Differential 540 response to climatic variation of free-floating and submerged macrophytes in ditches. $541 \quad$ Freshwater Biology 56: 1761-1768.

542 38. Nicotra A. B., O. K. Atkin, S. P. Bonser, A. M. Davidson, E. J. Finnegan, U. Mathesius, 543 P. Poot, M. D. Purugganan, C. L. Richards, F. Valladares \& M. van Kleunen,. 2010. Plant 544 phenotypic plasticity in a changing climate. Trends in Plant Science 15: 684-692.

545 39. Pagter, M., J. Alpers, A. Erban, J. Kopka, E. Zuther \& D. K. Hincha, 2017. Rapid 546 transcriptional and metabolic regulation of the deacclimation process in cold acclimated 547 Arabidopsis thaliana. Bio Med Central Genomics 18: 731.

548 40. Pilon, J. \& L. Santamaria, 2002. Clonal variation in the thermal response of the 549 submerged aquatic macrophyte Potamogeton pectinatus. Journal of Ecology 90: 141-152.

550 41. Puijalon, S., T. J. Bouma, J. M. Van Groenendael, \& G. Bornette, 2008. Clonal plasticity 551 of aquatic plant species submitted to mechanical stress: escape versus resistance strategy. 552 Annals of Botany 102(6): 989-996. https://doi.org/10.1093/aob/mcn190 
42. R Core Team, 2016. R: A Language and Environment for Statistical Computing. R Foundation for Statistical Computing, Vienna.

43. Rejmánková, E., 1992. Ecology of creeping macrophytes with special reference to Ludwigia peploides (H.B.K.) Raven. Aquatic Botany 43: 283-299.

44. Richards C. L., O. Bossdorf, N. Z. Muth, J. Gurevitch \& M. Pigliucci, 2006. Jack of all trades, master of some? On the role of phenotypic plasticity in plant invasions. Ecology Letters 9: 981-993.

45. Riis T., B. Olesen, J. S. Clayton, C. Lambertini, H. Brix \& B. Sorrel, 2012. Growth and morphology in relation to temperature and light availability during the establishment of three invasive aquatic plant species. Aquatic Botany 102: 56-60.

46. Ruaux, B., S. Greulich, J. Haury \& J.-P. Berton, 2009. Sexual reproduction of two alien invasive Ludwigia (Onagraceae) on the middle Loire River, France. Aquatic Botany 90: 143148.

47. Russell, V. L., 2016. Least-squares means: the R Package lsmeans. Journal of Statistical Software 69: 1-33.

48. Salinas M.J., J. J. Casas, J. Rubio-Ríos, E. López-Carrique, J. J. Ramos-Miras \& C. Gil, 2018. Climate-driven changes of riparian plant functional types in permanent headwater streams. Implications for stream food webs. PLoS ONE 13(6): e0199898.

49. Shulaev V., D. Cortes, G. Miller \& R. Mittler, 2008. Metabolomics for plant stress response, Physiologia Plantarum, 132: 199-208

50. Seneviratne, S. I., N. Nicholls, D. Easterling, C. M. Goodess, S. Kanae, J. Kossin, Y. Luo, J. Marengo, K. McInnes, M. Rahimi, M. Reichstein, A. Sorteberg, C. Vera, and X. Zhang, 2012. Changes in climate extremes and their impacts on the natural physical environment. In: Managing the Risks of Extreme Events and Disasters to Advance Climate Change Adaptation [Field, C.B., V. Barros, T.F. Stocker, D. Qin, D.J. Dokken, K.L. Ebi, M.D. Mastrandrea, K.J. 
578 Mach, G.-K. Plattner, S.K. Allen, M. Tignor, and P.M. Midgley (eds.)]. A Special Report of

579 Working Groups I and II of the Intergovernmental Panel on Climate Change (IPCC).

580 Cambridge University Press, Cambridge, UK, and New York, NY, USA, pp. 109-230.

581 51. Serra A-A., A. Nuttens, V. Larvor, D. Renault, I. Couée, C. Sulmon \& G. Gouesbet, 582 2013. Low environmentally-relevant levels of bioactive xenobiotics and associated degradation 583 products cause cryptic perturbations of metabolism and molecular stress responses in 584 Arabidopsis thaliana. Journal of Experimental Botany 64: 2753-2766.

585 52. Sulmon C., J. van Baaren, F. Cabello-Hurtado, G. Gouesbet, F. Hennion, C. Mony, D. 586 Renault, M. Bormans, A. El Amrani, C. Wiegand, C. Gérard, 2015. Abiotic stressors and stress 587 responses: what commonalities appear between species across biological organization levels? 588 Environmental Pollution 202: 66-77.

589 53. Sultan S. E. \& H. G. Spencer, 2002. Metapopulation structure favors plasticity over 590 local adaptation. The American Naturalist 160(2):271-283.

591 54. Sun C. X., X. X. Gao, M. Q. Li, J. Q. Fu \& Y. L. Zhang, 2016. Plastic responses in the 592 metabolome and functional traits of maize plants to temperature variations. Plant Biol. 18:249$593 \quad 261$

594 55. Thouvenot, L., J. Haury \& G. Thiebaut, 2013. A success story: water primroses, aquatic 595 plant pests. Aquatic Conservation: Marine and Freshwater Ecosystems 23: 790-803.

596 56. Thouvenot, L., C. Deleu, S. Berardocco, J. Haury \& G. Thiébaut, 2015. Characterization 597 of the salt stress vulnerability of three invasive freshwater plant species using a metabolic 598 profiling approach. Journal of Plant Physiology 175: 113-121.

599 57. Van Wijk, R.J., 1988. Ecological studies on Potamogeton pectinatusL. I. General 600 characteristics, biomass production and life-cycles under field conditions. Aquatic Botany 31 : $601 \quad 211-258$ 
602 58. Vicente O., M. Al Hassan \& M. Boscaiu, 2016. Contribution of Osmolyte 603 Accumulation to Abiotic Stress Tolerance in Wild Plants Adapted to Different Stressful 604 Environments. In: Iqbal N., Nazar R., A. Khan N. (eds) Osmolytes and Plants Acclimation 605 to Changing Environment: Emerging Omics Technologies. Springer, New Delhi.

606 59. Violle, C., M.-L. Navas, D. Vile, E. Kazakou, C. Fortunel, I. Hummel \& E. Garnier, 607 2007. Let the concept of trait be functional. Oikos 116: 882-892.

608 60. Yen, S. \& P. J. Myerscough, 1989. Co-existence of three species of amphibious plants 609 in relation to spatial and temporal variation: Investigation of plant responses. Australian Journal 610 of Ecology 14: 305-318.

611 61. Wersal, R.M., J.C. Cheshier, J.D Madsen., \& P.D Gerard. 2011. Phenology, starch 612 allocation, and environmental effects on Myriophyllum aquaticum. Aquatic Botany 95: 194613199.

614 62. Xu, J., Z. Chen, F. Wang, W. Jia \& Z. Xu, 2020. Combined transcriptomic and 615 metabolomic analyses uncover rearranged gene expression and metabolite metabolism in 616 tobacco during cold acclimation. Scientific Reports 10: 5242. 
Figure Caption

619 Figure 1. Morphological traits of six populations of L.peploides exposed at three temperatures. Different letters indicate significant differences for L. peploides with temperature and population (ANOVA, $\mathrm{p}<0.05$ ). Bars indicate standard deviation.

Figure 2: Responses of physiological traits of L. peploides populations coming from two different regions (Oceanic and Mediterranean regions) to three temperatures. NBI $=$ Nitrogen Balance Index, $\mathrm{Chl}=$ chlorophyll index, Flav $=$ flavonol index and Anth $=$ anthocyanin index.

Fig 3: A) Between-PCA based on the 25 metabolites identified and quantified by GC-MS. A plot of the first two principal components (PC1 vs. PC2) is shown in panel A. Lines link individuals to their respective centroids ( $\mathrm{n}=3$ to 5 ). Populations at 16,24 and $30^{\circ} \mathrm{C}$ are shown in blue, black, and red, respectively. B) Correlation circles from the PCA. C) Histogram of the 1000 simulated values of the Monte Carlo randomization test of the between-PCA. The observed value is given by the vertical line, at the right of the histogram $(P<0.001)$. D) Bar chart showing the percent of inertia explained by each principal component (PC) of the between PCA. Only the first two components (PC1, PC2) were considered (black bars), as they accounted for 68 and $18 \%$ of intertia respectively.

Fig.4: Changes in Malic acid, Fumaric acid, Aspartic acid, Succinic acid, Alanine and Lactic acid in seedlings of L. peploides exposed at three temperatures $\left(16^{\circ} \mathrm{C}, 24^{\circ} \mathrm{C}\right.$ and 30 ${ }^{\circ} \mathrm{C}$ ). The seedlings were issues from three Mediterranean populations (CAM, MACO, CCAP) and from three Oceanic populations (LRPV, LRJC, BRB). 
641 Table 1 - Location of six populations where the capsules of Ludwigia peploides subsp.

642 montevidensis were collected. M 1,2,3= Mediterranean region, O1,2,3= Oceanic region.

\begin{tabular}{lllc}
\hline $\begin{array}{l}\text { Seed source } \\
\text { region code }\end{array}$ & $\begin{array}{c}\text { Population } \\
\text { code }\end{array}$ & Name of waterbody - Site name & GPS coordinates \\
\hline M1 & CAM & Camargue & $43.535972 ; 4.753578$ \\
M2 & MACO & Marais de Coute & $43.584092 ; 4.366019$ \\
M3 & CCAP & Canal des Capettes & $43.606264 ; 4.336035$ \\
O1 & BRB & Brière & $47.32599 ;-2.267511$ \\
O2 & LRJC & Loire River at Ile Joli Coeur & $47.318086 ; 0.405323$ \\
O3 & LRPV & Loire River at Port de Vallieres & $47.386011 ; 0.608789$
\end{tabular}

643 
Table 2. Effects of the temperature, population and the interaction of these two terms on the morphological traits. The comparisons were made

645 by running generalized linear models with temperature and population as fixed and crossed variables. The effects of each variable and their

646 interaction were analyzed with ANOVA. The resulting values of the LR Chisquares, degree of freedom (df), and $\mathrm{p}$ values are presented in the table.

647 Significant differences $(\mathrm{p}<0.05)$ are in bold.

\begin{tabular}{|l|c|c|c|c|c|c|c|c|c|c|}
\hline \multicolumn{1}{|c|}{ Morphological traits } & \multicolumn{3}{|c|}{ Temperature effect } & \multicolumn{2}{c|}{ Population effect } & \multicolumn{3}{c|}{ Temperature x poplulation effect } \\
\hline & LR Chisq & $\mathrm{df}$ & $\mathrm{p}$ & LR Chisq & $\mathrm{df}$ & $\mathrm{p}$ & LR Chisq & $\mathrm{df}$ & $\mathrm{p}$ \\
Total biomass & 209.09 & 2 & $<\mathbf{0 . 0 0 1}$ & 170.68 & 5 & $<\mathbf{0 0 1}$ & 142.90 & 10 & $<\mathbf{0 . 0 0 1}$ \\
Below mass & 31.227 & 2 & $<\mathbf{0 . 0 0 1}$ & 34.408 & 5 & $<\mathbf{0 . 0 0 1}$ & 42.261 & 10 & $<\mathbf{0 . 0 0 1}$ \\
Aboveground mass & 218.94 & 2 & $<\mathbf{0 . 0 0 1}$ & 167.35 & 5 & $<\mathbf{0 . 0 0 1}$ & 143.65 & 10 & $<\mathbf{0 . 0 0 1}$ \\
Number of new leaves & 559.98 & 2 & $<\mathbf{0 . 0 0 1}$ & 36.35 & 5 & $<\mathbf{0 . 0 0 1}$ & 29.06 & 10 & $<\mathbf{0 . 0 0 1}$ \\
Number of branches & 550.32 & 2 & $<\mathbf{0 . 0 0 1}$ & 389.10 & 5 & $<\mathbf{0 . 0 0 1}$ & 229.72 & 10 & $<\mathbf{0 . 0 0 1}$ \\
RGR & 1282.13 & 2 & $<\mathbf{0 . 0 0 1}$ & 58.90 & 5 & $<\mathbf{0 . 0 0 1}$ & 30.26 & 10 & $<\mathbf{0 . 0 0 1}$ \\
\hline
\end{tabular}

649 
650 Table 3. Linear fixed model results. NBI = Nitrogen Balance Index, Chl $=$ chlorophyll index, Flav $=$ flavonol index and Anth $=$ anthocyanin index.

651 Significant p-values at 5\% significance level are in bold.

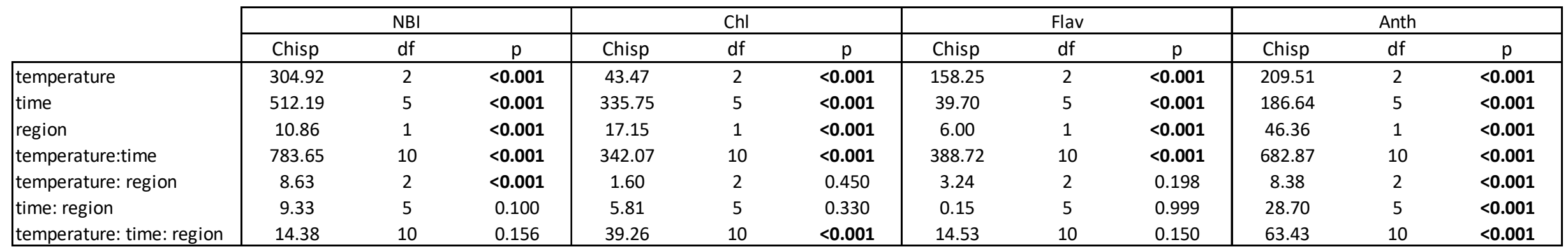


Page $31 / 31$ 